\title{
燃、料易展望 -30
}

\section{電力事業と燃料關係に就て}

福 谷貞 逸

\section{I＼cjkstart豐富低廉の電力を供給するには豐富低廉の石炭を要す}

電力を發生する資原飞は水力, 火力 (石炭), 夜體燃料, 風力, 潮流, 太陽熱等か有ります か，我國ては專ら水力と火力と飞據つて發電して居ります。水力は誠に天惠の資原て有り ますが，其の開發には莫大の資材と年月を要し，其の電原にも限度か有りますのみならす， 所謂水ものて渴水時には發電力か著咸されます。此の短所を補つて電力の供給を豐富安定 にするものは郎ち火力發電てあります。現今ては其の設備は大凡牛々てありまして，其の

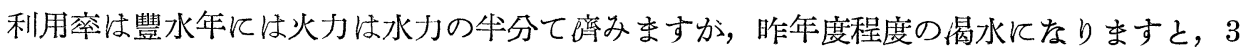
丵 2 位の割合て火力に依る補給發電を必要とします。從つて，電力國家管理の理想える， 豐富にして低廉なる電氣を供給するためには，低廉なる石炭か豊富に獲得されなくてはな りません。

電力國家管理の第 1 年飞於て未曾有の電力不足を惹起したのb，其の原因は炭質か惡く なつたのと，其の量か不足たつた孚に外ならぬのてあります。愒水を第1の原因にする人 もありますか，石炭さへ有れば，あの程度の渴水は火力，郎ち石炭飞依つて充分補給出來 たのてあります。

然し去る冬期重負荷時に 3 割，4 割といふ大幅の電力制限を行つた當時の實壯を顧みま すと，あの石炭ては量か豐富にあつたとしても，炭質不良か設備を損傷して，早晚は或る 程度の發電不足を生したに相違ない之想像されるので，正直に白狀すれば，量か不足した のて私共は助つたとさへ思はれるのてあります。

今日の非常時局に私共は助つてばかりは居られません。我國の基礎產業を確立する孚の 第一要件は石炭の質をよくするてと，次は必要量を充すととてあります。日本办强國に成 りをいといふ事は全國民の齊しく念願する所てありますか，資材のミしい今日念願するを゙ けて强くなれません。先つ努力する事か第一てす。頭を働かせる部門の人は更に働かして， 既設設備をるつと有效に運用して，以つて國力の充實を謀らなくてはなら媤ひます。 折角有る機械設備の能力なり, 容量を一杯と使はないて, 何時出來るやら分らぬ開發や增設 を待つとんふのてはとう为物足りません。我國の電力供給事業も同樣てありまして，其の 
設備に限度かむりますから，使用する石炭の質を良くして，容量一杯の發電をして，供給 を圓骫にする事か國策上の最大急務てあります。

此の目的飞向つては發電用に可及的啇性炭を供給する事と，不良炭の有效なる俏化方法 を考へる事か先决問題てありまして，量はかりありましても，岸質が不良て設備を透次損 傷して行つたのては，勞力及び修絟資材かそしく，修理に長日數を要する現壯を以つてし ては東亞の長期建設に大きい文障を起させる事は誰にも分る事と思ひます。

我國の發電事業に必要存石炭の約 8 割强は日本發送電て俏費されますか，當今ぼうい。 程度の石炭か發電事業用に使沈て居るかと申しますと，其の發熱量から見て，發電所設 計當時に見積つそ所謂設計カロリーとの比较が第1 表の如くなつて居ます(地或別に見て)。

\section{第 1 表 岩 質 低下 此 較}

\begin{tabular}{|c|c|c|c|c|}
\hline \multicolumn{2}{|c|}{ 地 域 別 } & 設計カロリー & 昭和 13 年度本均 & 昭朋 14 年度本均 \\
\hline 關 & 東 & $6,277 \mathrm{cal}$ & $6,257 \mathrm{cal}$ & $5,718 \mathrm{cal}$ \\
\hline 關 & 西 & 6,250 & 6,192 & 5,788 \\
\hline 中 & 國 & 5,469 & 4,961 & 4,381 \\
\hline 九 & 州 & 5,783 & 5,234 & 5,002 \\
\hline 四 & 國 & 6,500 & 6,300 & 5,382 \\
\hline \multicolumn{2}{|c|}{ 全國本均 } & 6,161 & 5,797 & 5,382 \\
\hline
\end{tabular}

斯くの如く昨年度は適性炭より約 $800 \mathrm{cal}$ 低位の石炭を使ひました。炭質か惡くなりま すと，使用する气罐數が增加して一面てミルの能率か降りますから 1 割 3 分の炭質低下に 依つて約 2 割强の發電力を减退させて居ります。昨年度入手した石炭を發淕量に依て內睪 して見ますと大體第 2 表の如くなつて居ります。

第 2 表 昭和 14 年度 發電用石㞸發埶量に依る內譯（速報に依る）

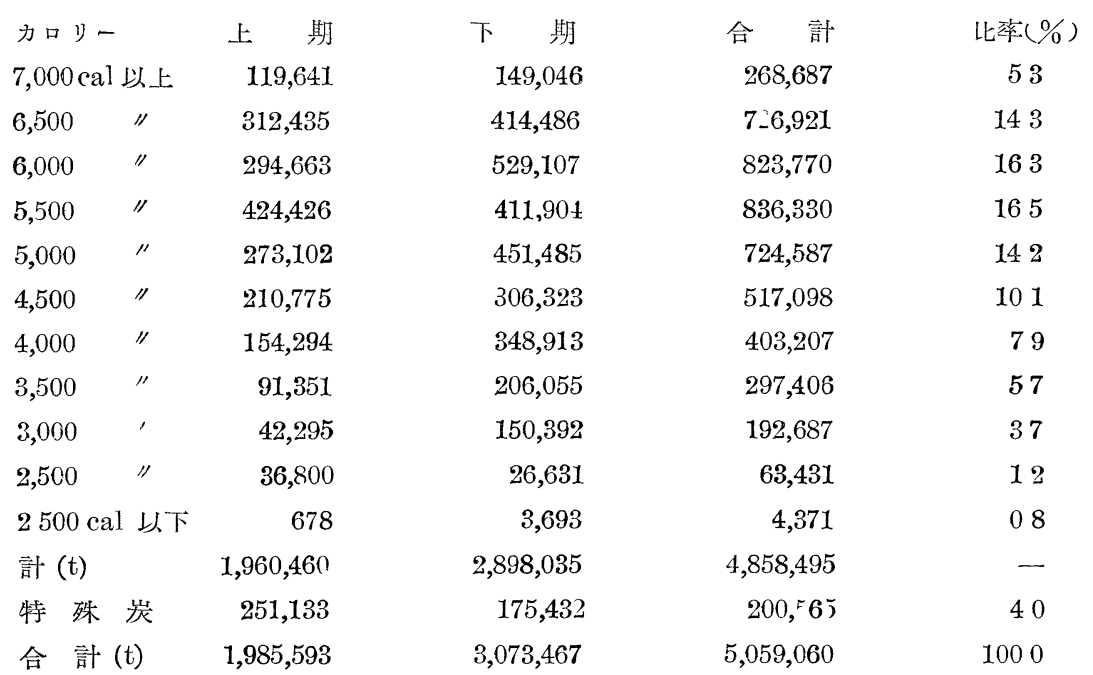

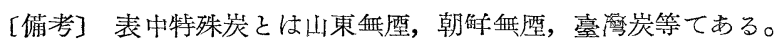




\section{II 電槑事菜に要する炭量と炭質の限度}

吾人か發電計畫を樹つるに際して知らねばならぬ條件は次の通りてあります。即ち 商工省か石岩購大中請飞對しては幾何許可してくれるか，

ぼの程度の石炭が契約出來るか，郎ち炭質如何，

納炭率をどう見てよいか，

水力の曷水程度如何,

保有し得る貯炭量は如何,

各發電所の可能發電力は如何。

往々世人は結果をけを見て禹角の批評を下すか，今日の社會清勢に於ては以上の條件中， 事前化知り得るものは只の一つとしてまりません。發電所の可能發電扎しても石炭次第 てありまして，石炭關係の見透しか判然と早く付く樣にならなりけれは，電氣供給の正し い計畫の立つのか遷延して，一般事業界，產業界に不安の念を增さしむるのてあります。

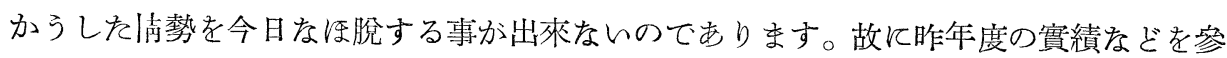
考にすることも此の際必要をと思ひますのて，茲泎年度の炭質，納炭率等を回顧して見 ますると大略第 3 表の如きものになつて居ります。

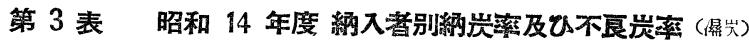

納大者昭伅會

上 $\underbrace{\text { 契約數量 }}_{(+)}{ }^{*}-952,550$

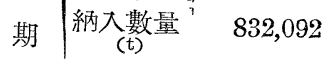

$\overbrace{14}$ 納入率

年 $\begin{array}{r}\text { (\%) } \\ 5000 \mathrm{cal}\end{array}$

\begin{tabular}{l|l}
49 & $5000 \mathrm{cal}$ \\
以 9 数是
\end{tabular}

月月 同 $(\%)$ 统

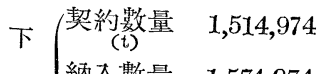

期 $\begin{gathered}\text { 䋑入數量 } \\ \text { ( })\end{gathered}$

$1415\{$ 納 大品

年年 (\%)

$103{ }^{5000 \mathrm{cal}}$

且月 $($ 同

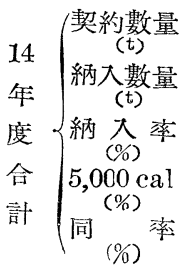

〔備考】上表中には宁部炭を含を。第 4 表と合計に戗らか差のあるは速報を集計した庐。

它 助 會

87

139,285

174

103

330,233

221

2,467,524

$2,406,196$

97

469,581

205
314,225

206,128

若松合名

541,920

332,709

65

30,900

159

370,871

362,759

98

39,222

116

685,006

568,887

83

90,122

131

61

178,496

490

643,219

490,637

76

319,267

686

$1,185,13$

823,3

601
アウト・

770,088

572,707

\begin{tabular}{rr}
$69 \quad 78$ \\
\hline
\end{tabular}

74

218,413

500

877,759

705,551

80

250,738

380

$1,647,847$

$1,278,258$

444
外國炭

- 257876

- $\quad 1,943,638$

- 75

28,991

64

- $1,506,614$

乾燥炭

$1,895,207$

- 567,094

- $\quad 306$

45,120

$3,451,943 \quad 3,020,646$

$3,451,943$

92

939,520

322

$6,030,706$

$5,105,680 \quad 4,915,853$

85

316 
次に産地別に之を見る時は概略第 4 表の樣になります。

\section{第 4 表 昭和 14 年度 産地别石㞸受入比較}

產 地 別

內 地 炭

北海道炭

權大 炭

臺 灣 炭

朝 解炭

山東炭

開本炭

滿洲炭

印度及カナタ

外地炭計

受大炭計

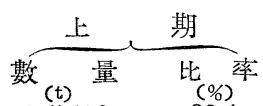

(t)
$1,675,976$

54,074

214,156

10,004

8,854

6,051

-

2,290

322,429

$1,998,405$

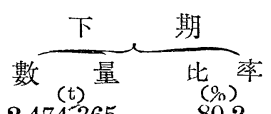

$2,474,365$

224,625

95,543

58,960

24,596

63,471

101,987

13,200

32,107

214,242

$3,068,854$

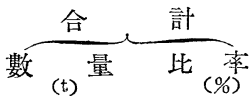

$4,130,341 \quad 815$

$278,699 \quad 55$

$336,699 \quad 66$

$68,964 \quad 13$

$33,450 \quad 07$

$69,522 \quad 14$

$101,987 \quad 20$

$15,490 \quad 03$

$32,107 \quad 06$

$936,918 \quad 185$

$5,067,295 \quad 1000$

本年度には電力需用の增加，發電所增設による出力增等によりまして，本水としまして も，發送電をけて 620 萬〜 630 萬 $\mathrm{t}$ の石炭か必要なのて专ります。此の内には若干の䝪炭 增量用の石炭か含まれて居りますか，俏費する石炭か乾喿炭にして 595 萬 $\mathrm{t}$ 以上必要之 なります。之は平均 $5,400 \mathrm{cal}$ 位の石炭を標隼としての數量てあります。此の石炭を短月 平均飞使用出來るものならば結構てありますか，4，5 月頃の豐水時には每月の使用量か2 20 〜30 萬 $\mathrm{t}$ て, 冬期重負荷期には一躍 100 萬 $\mathrm{t}$ 近くもの石炭を焚かなければならないの てあります。發送電の今日の設備ては1ヶ月に 100 萬 $\mathrm{t}$ の石炭か能率よく焚けませぬ。 全國平均して均一に焚くのならはいさ知らす，儿川に餘猶かあつて閣西の不足を補。事 か出來ねと言つた風て，月に 80 萬 $\mathrm{t}$ 以上石炭を焚くとなると，に゙うても炭質をよくし て量を 80 萬 $\mathrm{t}$ 位に制限しなければ，發電能力か所要電力量に達しないのであります。

日本發送電に於て將來適性炭と不良炭との割合をどの程度に貪はなければならねか，ま た不良炭をぼう消化して行くかを少しく次に速へて見をいと存しますか，何れにしまして も，我國の基礎產業を先づ安定して各種産業界に於ける動力に對する不安を除く孚に，

(1) 電氣事業界飞配給許可する炭量と炭質か早く头定さる〉とと,

(2) 販賣指圖を受けを數量は必す販賣して，購買契約上に未納炭を無くするてと，

(3) 石炭販賣契約に於て標隼カロทーと，最低保證品位との差をもつと近つけるとと (多いものは $1,000 \mathrm{cal}$ 以上もある),

（4）出炭，積出，輸送，荷役等の圓滑確實を圖り納期の正確を期し，渴水重負何期飞 於て揚炭能力の不足，带船等の支障を無からしむるとと，

（5）絕へす炭質調節用に 80 萬 $\mathrm{t}$ 以上の貯炭を保有する事を認むるとと， 之等の條件か1日8早く是正滿足さる〉事汃大切たと存して居ります。 


\section{III. 炭質劣下事情と其の對策}

我々の方で非適性炭, 又は不良炭と稱するのは略々下記の炭質に相等するものなのであ ります。

$\begin{array}{ll}\text { 發熱量 } & 5,000 \mathrm{cal} \text { 以下のもの } \\ \text { 炭粒 } 2 \text { 籷目䈐通過 } & 40 \% \text { 以上の子の } \\ \text { 灰熔融温度 } & 1300^{\circ} \mathrm{C} \text { 以下の子の } \\ \text { 揮發成分 } & 15 \% \text { 以小の無煙炭 } \\ \text { 强粘結性の石炭 } & \end{array}$

昨年度の炭質の趨勢は大略第 1 表，第 2 表に依つて窥はれますが，不良炭の率は次表の 如くなつて居ります。

\section{第 5 表 昭和 14 年度中 受入不脣岸量 (單位 $t$, 乾燥炭)}

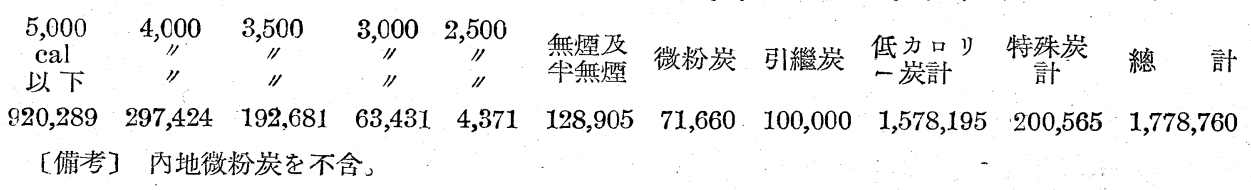

日本發送電が昨年創立當時前會より引續いた石炭と昨年度中に受入をした總炭量は 5,456,000 t (内 406,000 t は引續炭) 飞對し，不良炭の割合は $32.55 \% ，$ 此の內消費した不良 炭は $1,507,036 \mathrm{t}$ でありますから，14 年度不良炭消費割合蚔 $31.45 \%$ となります。そして 約 $271,714 \mathrm{t}$ を 15 年度に持越した譯であります。

昭和 15 年度上期の石炭も契約交捗が略及濟んだので，炭質は概略次の如く豫想される のであります。

本期中に受大すべき受大炭量及び不良炭量豫想は

$\begin{array}{lrl}5,000 \mathrm{cal} \text { 以上のもの } & 1,910,000 \mathrm{t} & 74 \% \\ 5,000 \mathrm{cal} \text { 以下の } & 675,000 " & 26 \%\end{array}$

炭種と依る內譯

$\begin{array}{lcc}\text { 適 性 炭 } & 912,000 \mathrm{t} & 35.3 \% \\ \text { 普 通 炭 } & 828,000 \text { ” } & 32.4 \% \\ \text { 不 良 炭 } & 844,000 ” & 32.3 ”\end{array}$

從つて今期の不良炭は持越分を合して 110 萬餘 $t$ となります。今期中に此の不良炭を 幾ら消化し得るかが問題であります。

日本發送電火力發電所の現在の燃燒設備から車します之, 各種設備の性能, 各利用率, 不良炭の混炭可能率及びキロ當り石炭消費率等から算定して，不良炭消化割合は大略次の 如くなります。
適性 炭
$64.5 \%$
不良炭
$35.5 \%$

之は宇部，戶畑，小倉等，不良炭を $60 \%$ 以上も焚く發電所を除いた率でありますが， 
相手の適性炭とは發電所の設計カロリーを標隼としたものてむりますから作均 5,700 cal 級の石炭と混合する場合飞は，上記，特殊發電所を包合しまして，不良炭俏化率は $36 \%$ 位を限度とするのてあります。

不良炭俏化對策としては次の如きととか考へられます。

本期中に不良炭を绡化し得る見込は，各發電所飞割當てを數量を墇賞て焚くとか，重伷

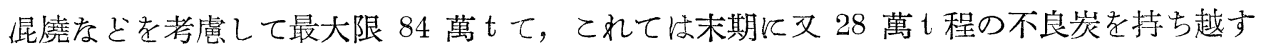
てとななります。

下期になりますと所要炭 370 萬 $\mathrm{t}$ の內, 從來通り $33 \%$ 位の割合て不良炭か大るとせ は，其の量は 122 萬 $\mathrm{t}$ 亿達し，持越不良炭と合して 150 萬 $\mathrm{t}$ の多量に上ります。然る に下期以冬期渴水て火力の重負荷期となりますのて，電気の全需要飞應する䇰飞發電容量， 即ち可能發電力を增大して所要炭全部を適性炭にしたい位て，不良炭の倱燒率はうんと低 下しますから，不良炭の手持ちは增加するはかりとなります。

此の倩勢がこ〉當分は續くものと見られますのて，我ふは適性炭の大手に努力する一面， 不良炭の俏化又は適性化几次の如き方釬を樹て〉進んて居ります。師ち

（1）適性炭との惃炭使用 (全般的)

（2）重伷及ひプロチューサー瓦斯との倱㾕（尼崎方面）

(3) 气罐燃燒裝置及ひ運炭設備の改造

（4）乾喿設備の新設 (鹤見, 湖田, 名巷, 木冿川, 尼崎等)

（5）選炭及ひ加工施設（細枌炭绲合, 壓控小粒化）

（6）有蓋貯炭場の增設

等これて, 臨時, 恒久兩方面と總ゆる努力を拂つて，不良炭の俏化に盡したいと存して 居ります。

紙面に制限かありますのて，之等計畫の內容說明は後日に讓らして致きます。 （15 6 15）（筆者は日本發运電株式會社發電棵長） 